\title{
The uptake of iso- flurane by the foetal lamb in utero: effect on regional blood flow
}

D.R. Biehl MD FRCP(C), R. Yarnell MD FRCP(c), J.G. Wade MD FRCP(C), D. Sitar PHD

In the foetal lamb, isoflurane anaesthesia produces

Because isoflurane has recently been approved for clinical use in anaesthesia, we have studied the effect of this agent in the foetus using the pregnant ewe as an animal model.

Eight pregnant ewes of 120-125 days gestation were surgically propared with indwelling catheters and tracheostomy. Prior to anaesthesia, labelled microspheres were injected into the foetal circulation to determine cardiac outpul and regional blood flows to all organs. The ewes were anaesthetized with a constant inspired concentration of 2.0 per cent isafurane in oxygen. Blood samples were drawn to construct an uptake curve for both mother and foetus. At 60 and 96 minutes of anaesthesia, microspheres were injected into the foetal circulation to measure changes in organ blood flow from the control period.

Isofiurane crossed the placenta and appeared in the foetal circulation within two minutes. By 96 minutes, maternal and foetal arserial levels were $116.3 \pm 9.9$ and $99.3 \pm 9.1 \mathrm{mEq} / \mathrm{L}(0.98 \mathrm{vol} \%$ and 0.75 vol\%). There were no significant changes in foetal blood pressure or pulse rate but foetal $p H$ decreased significantly from 7.39 \pm 0.02 to $7.26 \pm 0.2$ (mean \pm SEM) and base exces decreased from $-1.1 \pm 1.5$ to $-6.2 \pm 0.7$. Foetal cardiac index decreased from $390.8 \pm 26.9 \mathrm{ml} \cdot \mathrm{kg}^{-1}$. $\mathrm{min}^{-1}$ io $292.0 \pm 13.8$ after 96 minutes of anaesthesia. There were no significant changes in any of the maternal cardiovascular or acid-base parameters.

From the Departments of Anaesthesia and Pharmacology, Faculty of Medicine, University of Manitoba, Winnipeg, Manitoba.

Address correspondence to: Dr. Diane Biehl, Department of Anaesthesia, St. Boniface General Hospital, 409 Tache Street, Winnipeg, Manitoba, R2H 2 A6.

Supported in part by the St. Boniface Research Foundation, Grant no. RF-79.3 and the Medical Research Council of Canada, Grant No. MA-6735. foetal acidosis and decreases foetal cardiac index after 96 minutes of anaesthesia.

\section{Key words}

ANAESTHETICS, VOLATILE: isoflurane; ANAESTUESIA: obstetric; UTERLS: blood flow.

Isoflurane, a relatively new halogenated inhalation anaesthetic, has received extensive investigation in many clinical trials. ${ }^{1-3}$ The main advantages of this agent are its ease of administration, ${ }^{4}$ its minor degree of metabolism ${ }^{5}$ in the body and its less depressant effect on the cardiovascular system compared to halothane. ${ }^{6}$ This agent does not sensitize the myocardium to catecholamines and, thus, should not produce arthythmias on this basis. ${ }^{7}$ Isoflurane produces peripheral musculo-skeletal vasodilatation and lowers total peripheral resistance. ${ }^{8}$ It increases heart rate slightly and at 1 MAC levels cardiac output is maintained at awake values. ${ }^{9}$

Because of the above advantages of isoflurane for adults, this agent would be an acceptable alternative to halothane, or enflurane, in the parturient. Using the pregnant ewe as an animal model, Palahniuk and Shnider ${ }^{10}$ previously examined the effects of isoflurane on foetal cardiovascular haemodynamics and acid-base status and found that the effects were similar to halothane. Both agents significantly decreased foetal mean arterial blood pressure (MABP) but did not effect oxygenation or acid-base status.

We have used this same animal model but, in addition to the above factors, have measured foetal uptake of isoflurane in order to correlate haemodynamic changes with isoflurane blood levels and have, by using radioactive labelled microspheres, determined the effect of isoflurane on regional blood flows in the foetus. 


\section{Methods}

(a) Preparation of the model

Eight pregnant ewes of 125-135 days gestation (term 145-150 days) were surgically prepared as follows: under halothane in oxygen anaesthesia with controlled ventilation, polyvinyl catheters were inserted via a groin incision into the maternal femoral artery and vein. Through a midline abdominal incision the uterus was exposed and a small hysterotomy was made. Through the hysterotomy, foetal limbs were withdrawn for insertion of polyvinyl catheters into the foetal femoral artery and vein and axillary artery. All incisions were closed and the catheters tunnelled subcutaneously to the maternal flank and enclosed in a protective pocket. Each animal was allowed to recover for $24-36$ hours prior to the study.

\section{(b) Study period}

Prior to each study a tracheostomy was done on each ewe under local anaesthesia. Humidified oxygen was then administered through the tracheostomy at a flow of 10-12 litres. Each study began with a control period of 30 minutes with the ewe standing quietly in an experimental cart to ensure stability of the preparation. Maternal and foetal mean arterial blood pressure (MABP) and pulse rate were recorded continuously via the femoral arterial catheters on a Hewlett-Packard multi-channel recorder (Model 7758C). Maternal and foetal arterial blood gases and $\mathrm{pH}$ were measured at 15-minute intervals using a Corning blood gas analyser (Model 165/2). All foetal blood gas samples were drawn from the axillary artery.

In five studies, at the end of the control period, the first injection of labelled microspheres, either cerium $^{141}$, strontium $^{85}$, or chromium ${ }^{51}$ (3M Company, Minneapolis) was made into the foetal femoral vein. A suspension of $0.2 \mathrm{cc}$ containing $1.4 \times$ $10^{6}$ spheres of $15 \pm 0.5$ microns in diameter was injected over 15 seconds and flushed with $10 \mathrm{cc}$ of normal saline. Blood was constantly withdrawn from both the axillary and femoral arterial cannulas at a rate of $1.6 \mathrm{ml} \cdot \mathrm{min}^{-1}$ using a Harvard Pump (Model 940) beginning 30 seconds prior to injection and continuing for 150 seconds following the microsphere injection. The blood samples were weighed and the radioactivity counts were determined by a Searle Analytic Mark III gamma counter (Model No. 6880). "These served as reference samples for blood flow to organs above and below the ductus arteriosus.

Isoflurane, at an inspired concentration of $2.0 \mathrm{per}$ cent, was then added to the matemal breathing circuit. After approximately five minutes, ventilation was controlled to maintain maternal blood gases at control values. Two millilitres of arterial blood was withdrawn from the maternal femoral and foetal axillary arteries at $0,2,4,8,16,24,32$, 48,64 , and 96 minutes of isoflurane administration. The blood was drawn into heparinized glass syringes and stored at $0^{\circ} \mathrm{C}$ until the end of the experiment when the samples were analysed by gas-liquid chromatography. ${ }^{12}$ During anaesthesia, the ewe received $1000 \mathrm{cc}$ of nomal saline intravenously. As the ewe became anaesthetized and ventilation controlled, she was placed in a sitting position.

At 60 and 90 minutes of isoflurane anaesthesia, labelled microspheres were injected into the foetal circulation in the same manner as in the control period, using a different isotope label for each injection.

At the end of each study the animals were killed by an injection of thiopental sodium and saturated $\mathrm{KCl}$ and the foetus and placenta removed. The foetus was dissected and each organ system, including the skin and carcass, weighed, ground and ashed. The ashed samples were counted for radioactivity and these counts were compared to the reference samples to calculate the blood flow in each organ system. The total of all organ blood flows was considered to be the cardiac output of the foetus. This slightly underestimates true biventricular cardiac output because we did not have a reference sample for the lung, so did not calculate pulmonary blood flow. ${ }^{11}$ To correct for differences in foetal size, which is considerable during the last 20 days gestation in the sheep, the cardiac output was converted into a foctal cardiac index by dividing by foetal weight.

Analysis of results for maternal and foetal mean arterial blood pressure, pulse rate, blood gases and $\mathrm{pH}$ changes was by analysis of variance. Maternal and foetal isoflurane levels at each time period were compared by paired " $\mathrm{t}$ " test. Foctal regional blood flows and cardiac index changes for control, 60 and 90 minutes of isoflurane anaesthesia were tested for significance by analysis of variance. "P" $<0.05$ was considered significant. 
TABLE I Matemal and foetal mean anterial pressure and pulse rate during administration of $2.0 \%$ isofiurane to the pregnant ewe

\begin{tabular}{|c|c|c|c|c|c|c|c|c|c|}
\hline & \multirow[b]{2}{*}{ Contral } & \multicolumn{8}{|c|}{ Time (minutes) } \\
\hline & & 2 & 8 & 16 & 24 & 32 & 48 & 64 & 96 \\
\hline \multicolumn{10}{|l|}{ Maternal } \\
\hline MABP & 96.0 & 96.0 & 83.5 & 83.0 & 84.0 & 86.3 & 89.5 & 96.0 & 97.8 \\
\hline (torr) & \pm 1.1 & \pm 4.9 & \pm 7.46 & \pm 6.1 & \pm 5.3 & \pm 69 & \pm 7.7 & \pm 8.4 & \pm 9.1 \\
\hline Pulse rate & 102.6 & 112.5 & 102.6 & 111.0 & 99.4 & 93.1 & 98.1 & 107.5 & 106.2 \\
\hline (beats $/ \mathrm{min}$ ) & \pm 3.2 & \pm 6.8 & \pm 7.4 & \pm 11.2 & \pm 3.8 & \pm 4.9 & \pm 4.8 & \pm 6.5 & \pm 5.6 \\
\hline \multicolumn{10}{|l|}{ Foetal } \\
\hline MABP & 63.6 & 58.0 & 51,0 & 50.0 & 50.8 & 50.5 & 50.0 & 49.2 & 50.2 \\
\hline (torr) & \pm 3.4 & \pm 3.2 & \pm 3.5 & \pm 3.1 & \pm 3.9 & \pm 3.9 & \pm 3.7 & \pm 3.8 & \pm 4.3 \\
\hline Pulse rate & 164.0 & 169.0 & 165.0 & 166.0 & 160.0 & 158.0 & 156.0 & 1560 & 146.0 \\
\hline (bears/min) & \pm 8.7 & \pm 9.1 & \pm 9.6 & \pm 13.5 & \pm 13.5 & \pm 7.9 & \pm 7.5 & \pm 8.4 & \pm 8.4 \\
\hline
\end{tabular}

$\mathrm{N}=8$, Mean $\pm \mathrm{S} . \mathrm{E}$.

TABLE II Maternal and foetal blood gases and pH during administration of isoflurane to the pregnant ewe (2.0\% inspired concentration)

\begin{tabular}{|c|c|c|c|c|c|c|c|c|}
\hline & \multirow[b]{2}{*}{ Contral } & \multicolumn{7}{|c|}{ Time (minutes) } \\
\hline & & 8 & 16 & 24 & 32 & 48 & 64 & 96 \\
\hline \multicolumn{9}{|l|}{ Maternal } \\
\hline \multirow[t]{2}{*}{$\mathrm{pH}$ (units) } & 7.50 & 7,44 & 7.48 & 7.51 & 7.50 & 7.50 & 7.49 & 7.47 \\
\hline & \pm 0.02 & $=0.03$ & \pm 0.03 & \pm 0.03 & \pm 0.02 & \pm 0.02 & \pm 0.02 & \pm 0.03 \\
\hline \multirow[t]{2}{*}{$\mathrm{H}^{+}$nanomoles/l. } & 31.6 & 36.3 & 33.1 & 30.0 & 31.6 & 31.6 & 32.4 & 33.9 \\
\hline & \pm 1.4 & \pm 2.5 & \pm 1.5 & \pm 2.2 & \pm 1.4 & \pm 1.4 & \pm 1.5 & \pm 1.5 \\
\hline \multirow[t]{2}{*}{$\mathrm{PCO}_{2}$} & 29.0 & 33.0 & 30.0 & 30.0 & 28.0 & 30.0 & 29.0 & 34.0 \\
\hline & \pm 1.4 & \pm 2.1 & \pm 2.2 & \pm 1.1 & \pm 0.7 & \pm 1.2 & \pm 1.5 & \pm 2.6 \\
\hline \multirow[t]{2}{*}{$\mathrm{PO}_{2}$} & 185,0 & $351.0^{*}$ & $353.0^{*}$ & $363.0^{*}$ & $363.0^{*}$ & $361.0^{*}$ & $350.0^{*}$ & $322.0^{*}$ \\
\hline & \pm 4.1 & \pm 30.4 & \pm 27.8 & \pm 29.8 & \pm 24.8 & \pm 31.6 & \pm 30.2 & \pm 20.8 \\
\hline \multirow[t]{2}{*}{ B.E. } & 2.4 & -0.6 & 1.4 & 2.4 & 2.0 & 2.1 & 0.9 & 2.4 \\
\hline & \pm 0.8 & \pm 1.0 & \pm 0.8 & \pm 1.3 & \pm 1.5 & \pm 1.0 & \pm 0.8 & \pm 1.1 \\
\hline \multicolumn{9}{|l|}{ Foetal } \\
\hline \multirow[t]{2}{*}{$\mathrm{pH}$ (units) } & 7.39 & 7.35 & 7.38 & 7.37 & 7.35 & $7.34^{*}$ & $7.33^{*}$ & $7.26^{\star}$ \\
\hline & \pm 0.02 & \pm 0.02 & \pm 0.02 & \pm 0.02 & \pm 0.01 & $\pm 0.0 \mathrm{I}$ & \pm 0.02 & \pm 0.02 \\
\hline \multirow[t]{2}{*}{$\mathrm{H}^{+}$naniomoles $/ \mathrm{L}$} & 40.7 & 44.7 & 41.7 & 40.7 & 44.7 & $45.7^{*}$ & $46.8 *$ & $54.9^{*}$ \\
\hline & \pm 1.8 & \pm 2.1 & \pm 1.9 & \pm 1.9 & \pm 2.1 & \pm 1.0 & \pm 2.1 & \pm 2.2 \\
\hline \multirow[t]{2}{*}{$\mathrm{PCO}_{2}$} & 37.0 & 44.0 & 42.0 & 40.0 & 39.0 & 40.0 & 41.0 & 44.0 \\
\hline & \pm 1.8 & \pm 2.4 & \pm 2.8 & \pm 2.2 & \pm 2.2 & \pm 1.7 & \pm 2.2 & \pm 2.9 \\
\hline \multirow[t]{2}{*}{$\mathrm{PO}_{2}$} & 20.0 & 24.0 & 26.0 & 25.0 & 24.0 & 24.0 & 24.0 & 25.0 \\
\hline & \pm 1.2 & \pm 1.6 & \pm 1.3 & \pm 1.2 & \pm 1.2 & \pm 1.2 & \pm 1.3 & \pm 1.5 \\
\hline \multirow[t]{2}{*}{ B.E. } & -1.1 & -0.8 & +0.1 & -2.1 & -2.4 & -2.6 & $-3.2 *$ & $-6.2^{*}$ \\
\hline & \pm 1.5 & \pm 0.9 & \pm 1.8 & \pm 0.6 & \pm 0.6 & \pm 0.7 & \pm 0.9 & \pm 0.7 \\
\hline
\end{tabular}

$*_{p}<0.05$.

$N=8$, Mean $\pm S . E$

\section{Results}

During the administration of isoflurane to the pregnant ewe, maternal MABP tended to decline but no values were significantly different from control. There were no significant changes in pulse rate (Table I). Maternal $\mathrm{PCO}_{2}, \mathrm{pH}$ and $\mathrm{BE}$ did not vary significantly from control values. Maternal $\mathrm{PO}_{2}$ increased significantly after eight minutes of isoflurane anaesthesia with the institution of controlled ventilation (Table II). 
TABLE III The effect of isoflurane on foetal cardiac index* and regional blood in the normal foetal lamb in utero

\begin{tabular}{|c|c|c|c|}
\hline \multirow{2}{*}{$\begin{array}{l}\text { Organ blood flow } \\
\mathrm{ml} \cdot \mathrm{gm}^{-1} \cdot \mathrm{min}^{-1}\end{array}$} & \multicolumn{3}{|l|}{ Isofurane } \\
\hline & Control & $60 \mathrm{~min}$ & $90 \mathrm{~min}$ \\
\hline Brain & $1.12 \pm 0.17$ & $1.06 \pm 0.20$ & $1.25 \pm 0.11$ \\
\hline Myocardium & $1.12 \pm 0.23$ & $0.88 \pm 0.13$ & $0.95 \pm 0.11$ \\
\hline Splanchnic bed & $1.64 \pm 0.35$ & $1.46 \pm 0.31 \dagger$ & $1.52 \pm 0.51$ \\
\hline Musculo-skeletal & $0.34 \pm 0.03$ & $0.28 \pm 0.03$ & $0.29 \pm 0.03$ \\
\hline Skin & $0.15 \pm 0.02$ & $0.11 \pm 0.02$ & $0.11 \pm 0.02$ \\
\hline Placenta & $1.13 \pm 0.11$ & $0.86 \pm 0.09 \div$ & $0.83 \pm 0.11 f$ \\
\hline $\begin{array}{l}\text { Cardiac index* } \\
\qquad \mathrm{ml} \cdot \mathrm{kg}^{-1} \cdot \mathrm{min}^{-1}\end{array}$ & $390.8 \pm 26.9$ & $286.0 \pm 21.7 \dagger$ & $292.0 \pm 13.8 \dagger$ \\
\hline $\begin{array}{l}\text { Foctal isoflurane } \\
\text { arterial blood } \\
\text { level volume \% }\end{array}$ & 0 & $0.73=0.05$ & $0.75 \pm 0.08$ \\
\hline
\end{tabular}

*Foetal cardiac index = total cardiac output divided by foetal weight.

$t_{p}<0.05$ significantly different from control.

$\mathrm{N}=5$, Mean \pm S.E.

TABLE IV Maternal and foetal isoflurane levels during administration of isoflurane to the pregnant ewe at an inspired concentration of $2.0 \%$

\begin{tabular}{|c|c|c|c|c|c|c|c|c|c|c|}
\hline & \multicolumn{10}{|c|}{ Time (minutes) } \\
\hline & 0 & 2 & 4 & 8 & 16 & 24 & 32 & 48 & 64 & 96 \\
\hline $\begin{array}{l}\text { Maternal arterial } \\
\text { concentration } \mathrm{mg} \cdot \mathrm{L}^{-1}\end{array}$ & 0 & $\begin{array}{r}28.7 \\
\pm 3.4\end{array}$ & $\begin{array}{r}54.5 \\
\pm 9.5\end{array}$ & $\begin{array}{r}72.6 \\
\pm 9.7\end{array}$ & $\begin{array}{r}86.9 \\
+11.7\end{array}$ & $\begin{array}{r}97.1 \\
\pm 11.1\end{array}$ & $\begin{array}{r}94.5 \\
\pm 9.9\end{array}$ & $\begin{array}{l}105.6 \\
\pm 7.7\end{array}$ & $\begin{array}{r}117.8 \\
=12.2\end{array}$ & $\begin{array}{l}116.3 \\
\pm 9.9\end{array}$ \\
\hline $\begin{array}{l}\text { Foetal arterial } \\
\text { concentration } \mathrm{mg} \cdot \mathrm{L}^{-1}\end{array}$ & 0 & $\begin{aligned} & 15.2^{*} \\
\pm & 4.3\end{aligned}$ & $\begin{aligned} & 23.5^{*} \\
\pm & 5.5\end{aligned}$ & $\begin{array}{l}34.5^{*} \\
\pm 5.2\end{array}$ & $\begin{aligned} & 53.0^{*} \\
\pm & 6.8\end{aligned}$ & $\begin{aligned} & 58.8^{*} \\
+ & 5.7\end{aligned}$ & $\begin{array}{l}\quad 66.7^{*} \\
\pm 8.2\end{array}$ & $\begin{array}{l}77.5^{*} \\
\pm 7.9\end{array}$ & $\begin{aligned} & 85.7^{*} \\
\pm & 5.8\end{aligned}$ & $\begin{array}{l}99.3^{*} \\
\pm 9.1\end{array}$ \\
\hline
\end{tabular}

${ }^{*} p<0.05$ foetal levels significantly lower than maternal.

$(\mathrm{N}=8$, Mean \pm S.E. .

Foetal MABP declined from a control of $63.4 \pm$ 3.4 torr to $51.0 \pm 3.5$ tor after eight minutes of isoflurane anaesthesia and remained at this level for the duration of the experiment. This did not represent a significant difference from control values, however. Foetal heart rate was unchanged from control (Table I).

Foetal blood gases and $\mathrm{pH}$ remained stable until 48 minutes of isoflurane anaesthesia. From that point onward there was a significant fall in foetal $\mathrm{pH}$ and base excess. At 96 minutes of anaesthesia, foetal $\mathrm{pH}$ had declined from a control value of 7.39 \pm 0.02 (mean $\pm S E M$ ) to $7.26 \pm 0.02$. Base excess had decreased from $-1.1 \pm 1.5$ to $-6.2 \pm 0.7$.

Analysis of the microsphere data revealed a significant decrease in foetal cardiac index at both 60 and 96 minutes of isoflurane anaesthesia (Table III). This was accompanied by a significant fall in blood flow to the placenta at both 60 and 96 minutes and a significant decrease in splanchnic blood flow at 60 minutes, which returned to near control values by 96 minutes.

The uptake of isoflurane by the foetus is shown in Table IV in $\mathrm{mEq} / \mathrm{l}$ and in the Figure converted into volume per cent. Isoflurane crosses the placenta rapidly and appears in the foetal circulation within two minutes. Foetal arterial levels remain significantly below maternal arterial levels throughout the 96 minutes of anaesthesia. The uptake curve for the foetus parallels the maternal curve. 


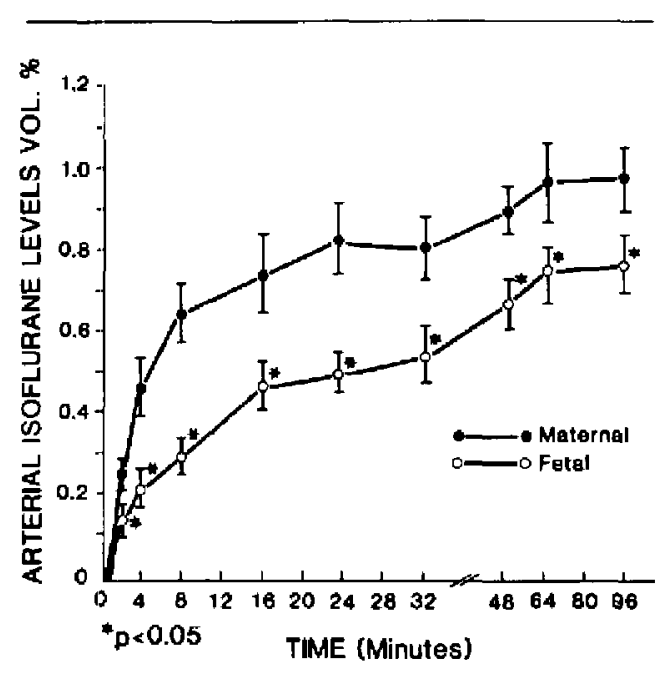

FIGURE Maternal and foctal arterial isoflurane levels during administration of isoflurane at an inspired concentration of $2.0 \%$ for 96 minutes. $(\mathrm{N}=8$ Mean \pm \$.E. $)$

\section{Discussion}

Isollurane uptake by the foetus is similar to that of halothane. ${ }^{13}$ Isoflurane crosses the placenta rapidly but foetal arterial levels rise slowly and after 90 minutes are still significantly less than maternal arterial levels. This may demonstrate the relative inefficiency of the placenta compared to the lung. Placental shunting in both the maternal and foetal circulations has been previously demonstrated ${ }^{14}$ and may account for the slower rise in foetal blood levels of isoflurane. Uptake of isoflurane by the foetal liver may also occur and, in part, account for the lower foetal arterial levels. The microsphere data demonstrate a significant fall in foetal placental blood flow. This would also impede uptake of isoflurane.

In our study of the normal foetal lamb, the MABP declined 20 per cent after eight minutes of isoflurane anaesthesia ( $P=N S$, analysis of variance). This is in contrast to our results with halothane (a significant fall of 33 per cent) ${ }^{13}$ and, also, the results obtained by Palahniuk and Shnider ${ }^{10}$ who found a progressive decrease in foetal MABP at 1 and $2 \mathrm{MAC}$ isoflurane. In our study, by 96 minutes, the maternal level of isoflurane was 1 MAC $\left(0.98\right.$ vol\%). ${ }^{10}$ We did not demonstrate an increase in musculo-skeletal blood fiow in the foetus either, as had been found in human studies with isoflurane. In the foetal lamb, isoflurane did appear to depress myocardial function as the foetal cardiac index declined significantly after 60 minutes of anaesthesia. The deterioration of foetal $\mathrm{pH}$ and base excess by 48 minutes of anaesthesia indirectly suggests that cardiac depression may have been occurring even earlier. As heart rate did not change during the period of anaesthesia, a decline in stroke volume, and thus contractility, likely accounts for the fall in cardiac index.

We also found that foetal blood flow to the placenta decreased significantly with isoflurane anaesthesia. This is in contrast to lambs anaesthetized with halothane, in which placental blood flow did not decline significantly. ${ }^{15}$ The decreased flow may represent shunting of blood away from the placenta, but this is unlikely because blood flow to other organs did not increase. It is probably a reflection of decreasing cardiac output. Splanchnic blood flow also decreased initially but then increased by 90 minutes to control values.

The effects of isoflurane on foetal status is one of progressive foetal acidosis, although significant acidosis and myocardial depression did not occur until one hour of anaesthesia. This is a much longer exposure than one would have, clinically, at Caesarean section or vaginal delivery. The normal foetus would likely tolerate short exposures to isoflurane, but the depressant effect in the stressed foetus might occur more quickly.

In view of the fact that halothane, in contrast to isoflurane, does not produce acidosis or a fall in foetal cardiac index - even after 90 minutes - there seems little reason at present to suggest that isoflurane be used instead of halothane for general anaesthesia in obstetrics.

\section{Acknowledgments}

We greatly appreciate the expert technical assistance of Ms. Maureen Cumming and Mr. Wayne Pucci in performing these studies. Special thanks to Mrs. Beverley Fewster for typing the manuscript.

\section{References}

1 Forrest JB, Buffington C, Calahan $M K$ et al. A multicentre clinical evaluation of isoflurane. Can Anaesth Soc J, 1982; 29 (Supplement).

2 Eger EI. Isoflurane: A compendium and reference. Airco Incorp, 1981. 
3 Vitche $J F$. A history of forane. Anesthesiology $1971 ; 35: 4-7$.

4 Homi $J$, Konchigeri $H N$, Echenhoff $J E$, Linde $H W$. A new anesthetic agent - Forane: Preliminary observations in man. Anesth Analg 1972; 51: 439-77.

5 Greenstein $L R$, Hiet RA, Mazze RI. Metabolism in vitro of enflurane, isofluranc and methoxyflurane. Anesthesiology 1975; 42: 420-4.

6 Cromwell TH, Stevens WC, Eger EI, II et al. The cardiovascular effects of compound 469 (Forane) during spontaneous ventilation and $\mathrm{CO}_{2}$ challenge in man. Anesthesiology 1971; 35: 17-25.

7 Johnston, RR, Eger EI, II, Wilson C. A comparative interaction of epinephrine with enflurane, isoflurane and halothane in man. Anesth Analg 1976; 55: 709-12

8 Stevens WC, Cromwell TH. Halsey MJ et al. The cardiovascular effects of a new inhalational agent, Forane, in human volunteess at constant arterial carbon dioxide tension. Anesthesiology 1971; 35: 8-16.

9 Tranow $J$, Eberlein $H J$. Oser G et al. Influence of modern inhalational agents on hemodynamics, myocardial contractility, left ventricular volumes and myocardial oxygen supply. Anaesthetist 1977; 26 . 220-30.

10 Palahniuk RJ, Shnider SM. Maternal and fetal cardioyascular and acjd-base changes during halothane and isoflurane anesthesia in the pregnant ewe. Anesthesiology 1974; 41 : 462-72.

11 Heyman BA, Payne BD, Hoffman JI er al. Blood flow measurements with cardionuclide-labelled particles. Prog Cardiovas Dis 1977; 20: 55-70.

12 Davies $D$. A method of gas chromatography using electron-capture detection tor the determination of blocd concentration of halothane, chloroform and trichloreythelene. Br J A naesth 1978; 50: 147-53.

13 Biehl DR, Cote J, Tweed WA et al. Uptake of halothane by the normal foetal lamb in utero. Can Anaesth Soc J 1983; 30: 24-7.

14 Mexchia $G$. Normal exchange of respiratory gases across the sheep placenta in respiratory gas exchange and blood flow in the placenta, LD Lango and $\mathrm{H}$ Bartel (Eds) DHEW Publication (NIH) 73-361, p. $229,1972$.

15 Biehl DR, Cote J, Tweed WA et al. The effect of halothane on regional blood flow and cardiac output in the normal fetal lamb in utero. Anes Analg (in press).
Résumé

L'approbation récente de l'isoflurane pour usage clinique en anesthésie nécessitait une étude de ses effets sur le fotus; elle fur réalisée sur la brebis gravide.

Des sondes à demeure ont été installées par manceuvres chirurgicales sur huit brebis gravides de 120 d̀ 125 jours qui furent aussi trachéotomisées. Avant l'anesthésie, des microsphères marquées ont été injectées dans la circulation fotale pour mesurer le débit cardiaque et les débits sanguins régionaux. Les brehis furent anesthésiées par inhalation d'une concentration inspirée constante de 2 pour cent d' isoflurane dans l'oxygène. Des échantillons furent prélevés pour tracer une caurbe de captare tant pour la mère que pour le factus. Après 60 et 96 minutes d'anesthésie, des microsphères furent injectées dans la circulation fatale pour mesurer les changements de débits régionaux comparatifs a la période de contróle.

L'isoflurane a traversé le placenta et est apparu dans le sang fatal en moins de deux minutes. A la 96ième minute, les niveaux artériels maternels et fortaur étaient respectivement de $116.3 \pm 9.9$ et de $99.3 \pm 9.110 .98 \mathrm{vol}$ pour cent et $0.75 \mathrm{vol}$. pour cent). Il n'y a pas eu de changemenis significatifs de la pression sanguine et da pouls foetaux mais le $\mathrm{pH}$ a baissé de façon significative de $7.39 \pm 0.02$ à $7.26 \pm 0.2$ et l'excès de base est passé de $-1.1 \pm 1.5 d-6.2 \pm 0.7$. L'index cardiaque fotal a diminué de $390.8 \pm 26.9 \mathrm{ml} \cdot \mathrm{kg}^{-1} \cdot \mathrm{min}^{-1}$ à $292.0 \pm 13.8$ après 96 minutes d'anesthésic. On n'a pas trouvé de changements significatifs dans les paramètres maternels cardiovasculaires et acido-basiques.

L'anesthésie à l'isoflurane produit chez le fatus de la brebis de l'acidose et diminue l'index cardiaque après 96 minutes d'anesthésie. 